\title{
光子を用いた量子情報科学と表面科学
}

\author{
竹 内 繁 樹 ${ }^{1,2}$ \\ ${ }^{1}$ 北海道大学電子科学研究所 - 001-0020 北海道札幌市北区北 20 条西 10 丁目 \\ ${ }^{2}$ 大阪大学産業科学研究所 国 567-0047 大阪府茨木市美穂ヶ丘 8-1
}

(2011 年 8 月 30 日受付；2011 年 10 月 6 日掲載決定)

\section{Photonic Quantum Information Science and Surface Science}

\author{
Shigeki TAKEUCHI ${ }^{1,2}$ \\ ${ }^{1}$ RIES, Hokkaido University, Sapporo, Hokkaido 001-0020 \\ ${ }^{2}$ ISIR, Osaka University, Ibaraki, Osaka 567-0047
}

(Received August 30, 2011 ; Accepted October 6, 2011)

\begin{abstract}
Recent works of the authors on quantum information science using photons are reviewed. After the general introduction of photonic quantum information science, unique nano photonic devices such as tapered optical fibers, microsphere resonators, and nano diamond crystals are explained and their relationship with surface science is discussed. In the latter half, the realization of optical quantum circuits, and the application of such quantum circuits for quantum metrology are explained.
\end{abstract}

KEYWORDS : photon, quantum information, quantum optics, quantum circuits, nano photonics

\section{1.は じめに}

光子を用いた量子情報科学と聞くと，「自分の専門の 表面科学とは関係がない」とお考えの方も多いのではな いだろうか。しかし，量子情報科学では，これまでの技 術の延長線上にない，極めてデリケートなナノデバイス が要求される。たとえば，デバイスの表面における光子 と単一発光体の相互作用の制御などである。このような 光量子情報デバイス開発は, 私見では, 表面科学の新し い研究テーマの宝庫である。

また, 光子を用いた量子情報科学は, 「複数プロセス 間の量子干渉を自在に操る，デザインする」という，人 類がこれまで行い得なかったことを，まだまだごく小規 模ではあるが，実現しつつある。その応用は，よく言わ れる量子コンピュータや量子暗号だけではなく, 光計測 やシミュレーションまで多岐にわたり研究が進められて いる。

本稿は, 表面科学の研究に携わっていらっしゃる皆様

E-mail : takeuchi@es.hokudai.ac.jp
に，光子を用いた量子情報科学が「何が面白いのか」 「何ができるのか」「どこまで進んでいるのか」を知って 頂くことが目的である。また, 我々の, ナノフォトニク スデバイスの研究を例にして, 表面科学的な課題の具体 的な例についても紹介する。

\section{2. 光子を用いた量子情報科学とは}

\section{1 量子情報科学とは}

量子情報科学の研究とは, 「量子力学的な状態に情報 を載せることで, 通常の（古典理論に基づく）情報処理 では得られない機能を見出す」ことである。ここで, 古 典理論とは, 電磁気学やニュートン力学を指す。現在, 一般に用いられている情報処理機器は, 古典理論に基づ いている。その基本部分を, 量子力学に置き換えること で，新たな可能性を見出す試みである。

量子情報科学の研究は, 1984 年の Bennett と Brassard による量子暗号 ${ }^{1)}, 1985$ 年の Deutsch による量子計算の 提案 ${ }^{2}$ により始まった。

量子暗号は, 光子一つ一つを送受信することで, 安全 な暗号通信で必要となる長大な乱数列を，遠く離れた 2 
者間で，秘密に共有するアイデアである。もし，送信さ れている光子が垂直, もしくは水平偏光だけだと知って いれば，100\% 正確に受信することが可能である。しか し，そこに斜め 45 度偏光の光子が混ざった場合，「不確 定性原理」により，もはや正確に受信することができ ず，もし盗聴すると，どうしてもその痕跡を送受信者に 残さざるを得ない。より詳しい原理に興味がある読者 は, 解説 ${ }^{3)}$ や入門書 ${ }^{4)}$ 参照して欲しい。この量子暗号 は，物理学的に安全性を保証できるとして注目され開発 が進められ，2010 年には日本でも，東京の中心部で 50 $\mathrm{km}$ 程度の回線を組み合わせたネットワークを用いて, 音声・ビデオ通信穾験などが行われている5 。

量子計算は, 量子力学的な重数合わせ状態を利用し て, 莫大な並列処理を実現するアイデアである2,4)。電 子や光子などの素粒子は, 同時に複数の状態に存在する 「重ね合わせ状態」をとる。たとえば，電子スピン（1/ 2）を例にとると, 電子が一つの時は上向き, 下向きの 二つの状態（これらを基底状態と呼ぶ）とそれらの重ね 合わせ状態になっている。このとき, 電子の数が 2 個, 3 個と増えると, 基底状態の数は, 4 個，8個と増える。 もし電子 100 個の状態を考えると, その基底状態は 10 の 30 乗個にも達する。量子計算では，このような莫大 な数の重㸚合わせ状態を適切に操作することで，ある種 の計算を，「古典的な」コンピュータよりも圧倒的に高 速に実行できると考えられている。その例が因数分解で あり, 10000 标の数の因数分解には, スーパーコンピュ ータでも 1000 億年といった時間が必要となるが, 量子 コンピュータが実現すれば，数日程度で解けると考えら れている。

この二つ以外にも, 高感度計測（量子メトロロジーと 呼ばれる）や，物性科学などの分野へも応用は拡がりつ つある。これらについては追って紹介する。

\section{2 光子を用いた量子情報技術}

量子情報の担体としては, 電子スピン, 原子核スピ ン, 超伝導素子など様々な研究が進められている。それ らの中でも光子は，重要な担体である。

第一に, 光子は長距離伝送が可能である。量子暗号実 験において, $100 \mathrm{~km}$ 以上の距離，重ね合わせ状態を保 ったまま光子を伝送する実験が行われている。このた め，量子通信などとの適合性が極めて良い。

次に, 他の量子に比べて, 精度高く制御が可能であ る。たとえば, 光子の偏光状態は, 市販の素子を用いて も，10の 5 乗程度の精度で検出・制御が可能である。

既に, 平均光子数が 1 より十分小さく減光されたレー ザー光と, 市販の光子検出器を組み合わせて, 実用に耐 える量子暗号実験などが行われているが，光子を用いた
量子情報処理をより高度化, 高機能化するためには, 単 一光子源, 光子検出器, 光量子メモリ, 光量子ゲートな ど, 従来のデバイスの延長上にはない様々なデバイスが 不可欠である。

たとえば，単一光子源とは，光子を一つずつ発生する 素子である。現在は, 非線形光学結晶中で, 一つの光子 が, エネルギーが半分の二つ光子へと分裂する過程（パ ラメトリック下方変換）が広く利用されているが，この 方式は, 効率の向上と共に 2 個以上の光子が同時に射出 される確率が増えてしまうという問題を抱えている。そ れに代わる物として, 次節で紹介するような, 半導体量 子ドットなどを用いたナノフォトニクスデバイスの研究 が進められている。

\section{3. ナノフォトニック量子デバイス}

\section{1 テーパー光ファイバや微小球共振器を利用した ナノフォトニックデバイス}

光量子情報デバイスの実現に向けたナノフォトニクス デバイスとして, 我々は, ナノ光ファイバや, 微小球共 振器に着目して研究を進めている。

テーパー光ファイバとは, 直径が $125 \mu \mathrm{m}$ の通常の光 ファイバを直径が $1 \mu \mathrm{m}$ 以下にまで引き延ばしたもので ある (Fig. 1) ${ }^{6}$ 。通常の光ファイバは, 光ファイバのコ ア部とクラッド部のガラスの屈折率差で光を閉じ込める が, テーパー光ファイバのテーパー部では, ガラスと空 気の屈折率差によって, 光は閉じ达められて伝搬する。 特に, その直径が光の波長の半分程度, 可視光の場合 $300 \mathrm{~nm}$ 程度にまで達すると, 光は回折限界に近い非常 に強い強度で集光され, かつ, テーパー部のガラスから 強くしみだして伝搬する。その際，ガラス表面の電場強 度は, 中心強度の 3 分の 1 程度にまで達する。すなわ ち，テーパーファイバを伝搬する光子と，表面の発光体 は非常に強く相互作用する。

さらに, 共振器電磁気学効果に類した現象により, テ

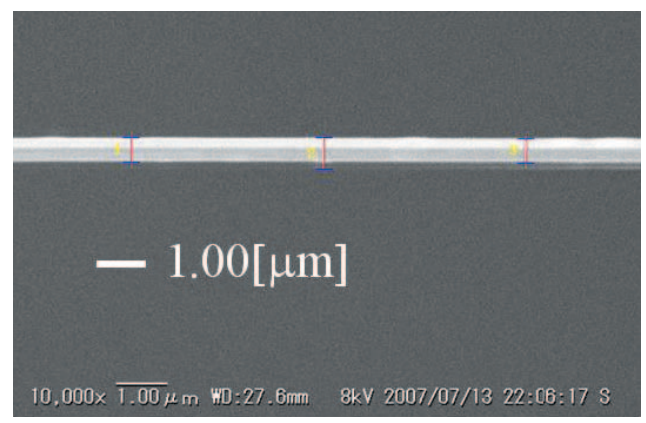

Fig. 1. (color online). The tapered region of a tapered optical fiber. 
ーパー光ファイバの表面の発光体から射出される光子 は, 非常に効率よくテーパー光ファイバに結合すること ができる。最近我々は, 直径 $300 \mathrm{~nm}$ のテーパー光ファ イバ上に付着させた $\mathrm{CdSe} / \mathrm{ZnS}$ 単一量子ドットの発光 が, 単一モードファイバに $7.4 \%$ 結合していることを確 認した7)。これは, SIL（Solid Immersion Lens）と顕微光 学系の組み合わせによる単一モードファイバへの結合効 率を凌駕する值である。今後, 高効率単一光子源への応 用が期待されるが, 表面科学研究への応用も可能ではな いだろうか。

\section{2 不可欠な, 表面科学的アプローチ}

単一発光体として, ダイヤモンド中の窒素欠陥（Nitorogen Vacancy, NV) 中心が注目されている。コロイド から形成した半導体量子ドットや色素と異なり, 非常に 安定であること, 長い位相緩和時間を有することが特徴 である。また，電子を補足してイオン化した NV $\left(\mathrm{NV}^{-}\right)$の電子スピンと, 周囲の炭素原子の核スピンを 利用して, 単一の核スピンの測定や, 核スピン間の量子 もつれ合い制御などが実現している。これらの技術の, 高感度ナノスケール磁気測定への応用も期待されている。 直径が数 $\mathrm{nm}$ から数十 $\mathrm{nm}$ の, ダイヤモンドナノ結晶 に含まれる $\mathrm{NV}^{-}$は，ナノフォトニクスデバイスと結合 させることで, 単一光子源や量子ゲートなどの単一発光 体として用いることができる。しかし従来, ナノ結晶中 の $\mathrm{NV}^{-}$では, フォノンを介した緩和発光（フォノンサ イドバンド）が強く存在するという問題があった。

最近我々は，この $\mathrm{NV}^{-}$のフォノンサイドバンドが, ダイヤモンドナノ結晶を分散させる基板によって大きく 影響を受けることを見出した ${ }^{8)}$ 。残念ながら，この現象 の仕組みはよくわかっていないが, 基板表面, および, ダイヤモンドナノ結晶表面の物性が関係していることは 間違いない。

他にも， $\mathrm{NV}^{-}$のゼロフォノン線は，発光励起（PhotoLuminescence Excitation, PLE) スペクトルからは 6-12 $\mathrm{MHz}$ という非常に小さな值が報告されているが，一方 で，共鳴線の位置が時々刻々と変化する（Spectral Diffusion）ことが知られている ${ }^{9)}$ 。特にナノ結晶中の $\mathrm{NV}^{-}$に おいて顕著とされている。これは, 光量子情報デバイス として利用するにあたって大きな問題である。しかし， その原因はよくわかっておらず，ダイヤモンドの表面で の帯電などの可能性が考えられている。

これらは, 光量子情報デバイスに対する表面科学の重 要性のほんの一例に過ぎない。量子情報デバイスは，量 子性を発現させるためにそのサイズは一般に小さい，つ まり表面の影響は極めて大きい。さらに，量子重ね合わ せ状態の破壊（デコヒーレンス）は，そのような表面で
の電子やフォノンの状態に強く影響を受ける。ぜひ，表 面科学の視点から，量子情報デバイスにも関心を持って 頂けると幸いである。

\section{4. 光量子回路の最新成果}

\section{1 複数光子の量子干渉}

本節では，これまで我々が実現した光量子回路の例を 紹介するが，その前にその基本となる，2 光子量子干涉 について説明しよう。

ところで，反射率が $50 \%$ の半透鏡に，光子を一つず つ同時に入射すると，光子は半透鏡で反射または透過す るため, Fig. 2 に示す 4 つの物理過程が存在する。この うち右側の二つ，「雨方の光子が反射」と「両方の光子 が透過」は，入力，出力ともにまったく同じ状態で区別 が付かないため, 両者の過程は「干涉」する。この時, これら二つの過程の確率振幅は，大きさが同じで符号が 逆のため完全に打ち消し合う。結果として，右側二つの 事象は生じず，光子はかならず二つが一緒に出力され る。この「2 光子量子干涉」は 1988 年に Mandel らによ って発見されていた ${ }^{10)}$ 。

\section{2 量子もつれフィルター}

我々は，この原理を利用した，入力された二つの光子 からもつれ合い状態を抽出する光量子回路（量子もつれ 合いフィルター）の実現に成功した ${ }^{11}$ 。

もつれ合いフィルターは, 入力された二つの光子の $\lceil$ 両方垂直偏光」もしくは「両方水平偏光」の状態のみ を，その状態間の重ね合わせを保ったまま透過する働き をする（Fig. 3)。このもつれ合いフィルターに，斜め 45 度偏光の光子を二つ入射すれば，オンデマンドのも つれ合い光子源として機能する。その他, 量子もつれ合 いの純化や，検出など，量子情報通信処理上の様々な利

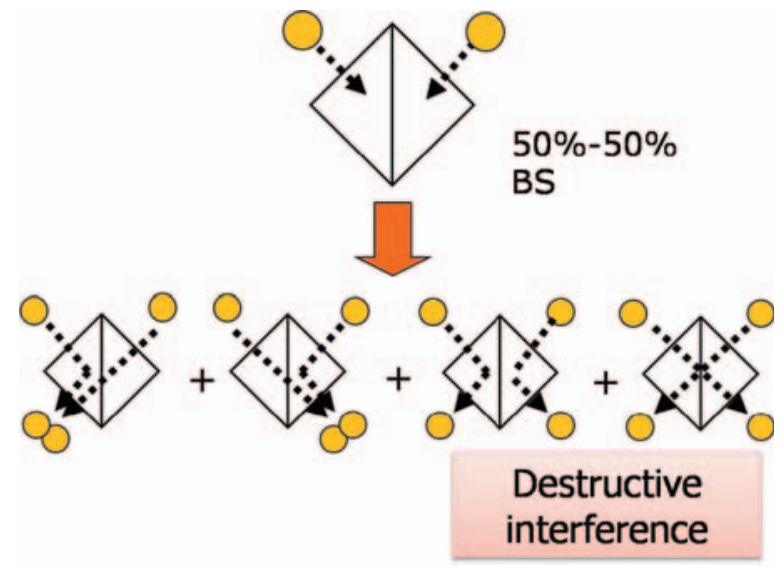

Fig. 2. (color online). Two photon quantum interference. 


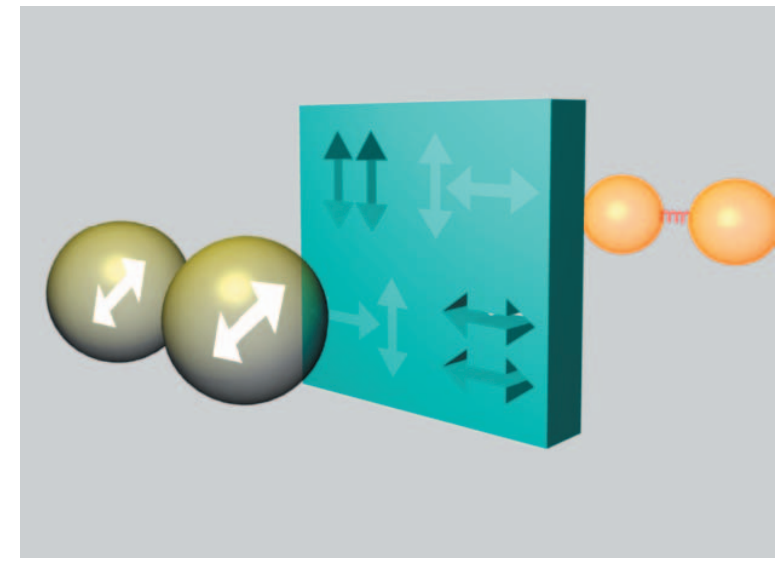

Fig. 3. (color online). Conceptual image of an entanglement filter.

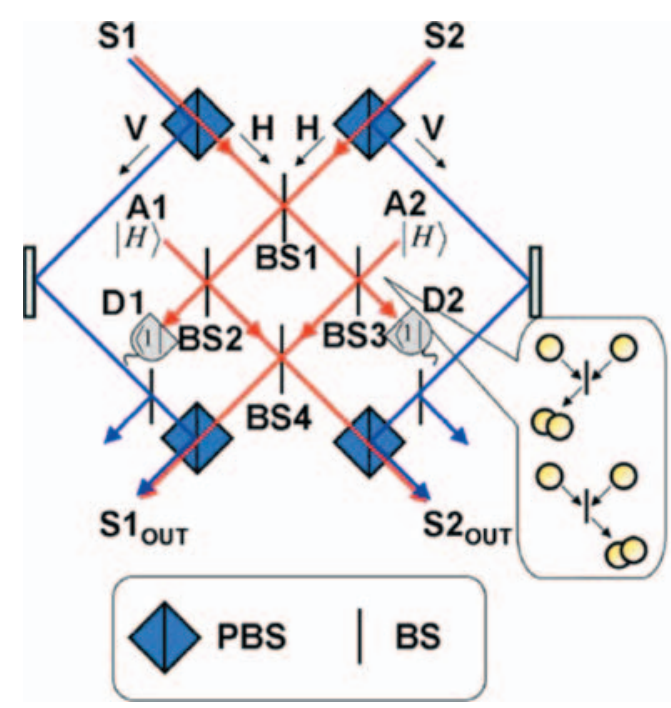

Fig. 4. (color online). Theoretically proposed optical circuit for an entanglement filter. Two signal photons are input to S1 and S2, and output from S1 out and S2out. $\mathrm{H}$ and $\mathrm{V}$ denote horizontal and vertical polarization respectively. PBS, BS, D are for polarizing beam splitter, beam splitter, and photon detector. $|\mathrm{H}\rangle$ denotes ancillary photon with horizontal polarization.

用が考えられる。

このような量子もつれ合いフィルターを実現する光回 路を, 我々は 2002 年に提案した ${ }^{12)}$ 。これは, 半透鏡で の補助光子と入力光子との 2 光子量子干渉を利用して, 入力光子数の非破壊検出ができるという独自の着想にも とづくものである（Fig. 4)。半透鏡に光子がひとつずつ 入射した場合には, 光子は二つ一緒に出力されるため, 補助光子 (A2) と同時に入力した状態が 1 光子の際に は, 設置した検出器（D2）で光子が一つ検出されるこ
とはない。それ以外の入力に対しては, 検出器で光子が 一つ検出される場合がある。このことを利用すれば，経 路に光子が一つだけ存在する場合を選ぶことが可能であ る。Fig. 4 の光回路では, これにさらに別の二つの半透 鏡（BS1, BS4）での 2 光子干渉を組み合わせることで, 入力された光子の偏光が異なる場合のみを検出, 排除で きるように工夫している。

しかし, この提案は, 4 か所において良質な 2 光子量 子干渉が必要で, かつ, 入れ籠状の干渉計の 4 つの経路 長を, ナノメートルで一致させなければならない, など の困難があった。我々は, 独自に発案した部分偏光ビー ムスプリッタ, ならびに変形サニャック型干渉構造で, 干渉計の安定化の問題を解決し, また, 独立した光子源 間で良好な量子干渉 (86\%) を達成することで, 量子も つれ合いフィルタの実現に成功した ${ }^{11)}$ 。実験では, 垂 直 - 水平偏光基底での理想的な入出力に対する忠実度は 0.8 , デバイスの量子性を示す指標であるもつれ合い能 力 (Entanglement Capability) は 0.08 と 0 より大きく, その非古典的な動作を確認した。これは, 合計 4 個の入 力光子に対して, 4 つの量子ゲート（2 光子干渉）を素 子として内包する, 世界最大級の光量子回路である。

\section{3 非線形素子を組み合わせた量子ゲート回路}

2001 年に, 米国抢よびオーストラリアのグループ (Knill, Laflamme, Milburn) は, 半透鏡で生じる量子干渉 を利用して, 光子 1 個レベルで動作する「非線形スイッ チ」が実現できること，またそのようなスイッチを組み 合わせることで, 光量子コンピュータが実現できること を示した ${ }^{13)}$ 。この提案は大変注目されたが, 半透鏡上で の光子間の良質な量子干涉が必要となること, また 4 つ の異なる光の経路を, ナノメートルの精度で一致させる 必要があるなど, その技術的な困難さから, 提案後 10 年間実現されていなかった。

最近我々は, 量子干渉をさらに向上（90\%）させた光 子源や, 特殊な半透鏡や光の干渉装置を工夫すること で，コンパクトで非常に安定した実装を実現し，Knill らの提案した, 光子 1 個レベルで動作する「非線形スイ ッチ」を組み合わせた光量子回路を実現することに成功 した ${ }^{14)}$ 。

\section{5. 超高感度光計測への応用}

次に, 光量子情報 - 光量子回路の, 計測への応用につ いて紹介しょう。

異なる経路を通る光線の間での干涉を利用した光の位 相測定は, 距離や物質の密度などを精密に測定する方法 として, 天文学から生物学まで様々な分野で利用されて いる。しかし, 古典理論 (古典光学) では, その測定精 


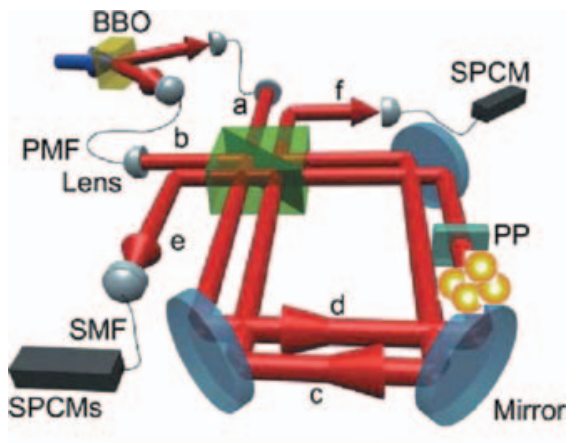

$$
\left(|4\rangle_{c}|0\rangle_{d}+|0\rangle_{c}|4\rangle_{d}\right) / \sqrt{2}
$$

Fig. 5. (color online). A four photon interferometer. BBO is a nonlinear crystal for parametric down conversion, PMF and SPCM(s) are for polarization maintaining fiber and single photon counting module (s) respectively.

度に, 通常用いる光の強度によって決まる限界が存在す る。一方, 量子論では, 複数の光子がもつれあった状態 により, その限界を超えることができる。我々は, 4 光 子もつれ合い状態を高精度で実現し, 独自の工夫で実現 した非常に安定な光干渉装置により, 古典理論による限 界を超えた測定感度を達成した ${ }^{15)}$ 。

Fig. 5 に実験装置を示す。非線形光学結晶（BBO）か ら, パラメトリック下方変換過程を用いて, 二つの 2 光 子状態を対として発生させ, それを半透鏡の入力 $\mathrm{a}, \mathrm{b}$ に入射させる。半透鏡では, Fig. 2 で述べたのと類似し た量子干渉によって,「4 光子状態が経路 c を伝搬する 状態」と,「4 光子状態が経路 $\mathrm{d}$ を伝搬する状態」の重 ね合わせ状態が生じる。光学ガラスでできた位相板 （PP）を通過する際, 4 光子状態は, 1 光子状態の 4 倍 の位相因子がかかるため, その干渉結果の周期は, 1 光 子干渉に比べて 4 分の 1 となる。結果として, 干渉縞の 最大傾きは 4 倍となり, その分位相差の微小な変化に対 し 4 倍の精度が得られる。利用する光子数を同じ条件と した精度 (=感度) では, 1 光子干渉実験を 4 回繰りか えした場合 (標準量子限界) に比べて, 理想的には 2 倍 の感度が得られる。

実験の結果, 同じ量の位相差の変化に対し, 2 光子も つれ状態干涉 (Fig. 6B), 4 光子もつれ状態干渉 (Fig. 6C）は 1 光子干渉（Fig. 6A）にくらべて周期がそれぞ れ 2 分の $1 ４$ 分の 1 になっている。このスキームでは, 多光子干涉の検出方法などでの損失なども考慮した場 合, 4 光子干渉の明瞭度が約 $82 \%$ 以上のときに標準量 子限界を超えうるが, 得られた明瞭度は $91 \%$ と十分に 大きいものとなった。
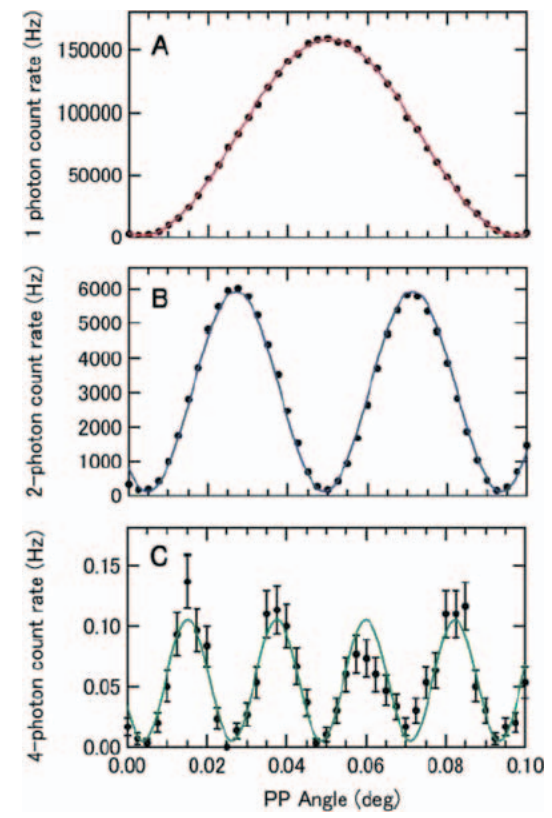

Fig. 6. (color online). Interference fringes of the multiphoton interferences. (A) single photon state (B) two photon path-entangled state $(\mathrm{C})$ four photon pathentangled state.

また，本論文は，この位相測定感度が標準量子限界を 超えること（位相超感度, phase super-sensitivity）こそ が, 非古典的な状態による量子干渉の証明であること を，実験的に明らかにした。従来，「1光子干涉よりも 周期の小さい干涉縞」の観測 (位相超分解, phase super resolution）が, 非古典的な状態の証明と考えられてき た。しかし, 本論文では, 通常の 1 光子干涉の組み合わ せでも, Fig. 6C に類似した, 位相超分解が得られるこ と, しかしその場合には実効的な損失を考慮すると, 100\%の明瞭度であっても標準量子限界を超えることが できないことを実験と共に示した。この検証では，2光

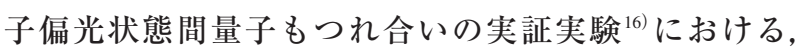
「区別できない 2 光子が同じ時空点に存在する状態 $(2$ 光子状態 $) 」 と 「 二 つ の$ 光子が隣接して存在する状態」 の判別方法を応用した。

現時点では技術的に困難ではあるが, 将来, 10000 個 の光子のもつれ合い状態が実現すれば, 位相測定感度は レーザー光の 100 倍になりうる。現在, 光損失が存在す る場合にどの程度の感度向上が可能か, その場合の最適 なスキームはどのようなものか, といった研究が進めら れている。

\section{6. ま め}

本稿では, 表面科学の研究に携わっていらっしゃる皆 
様に，光子を用いた量子情報科学が「何が面白いのか」 「何ができるのか」「どこまで進んでいるのか」を知って 頂くことを目的に，筆を進めてきた。

「プロセスの量子力学的な干渉」を操ることで, 従来 の方法では実現不可能な情報処理や, 高感度計測を原理 的には実現できること，またそのためには，従来とは大 きくことなるデバイスが必要になり, その研究は, 表面 科学を含めた, さまざまな学問にとっても, 未開拓でか つ大きな収穫が期待できるフィールドであることを，お 伝えできたであろうか。本稿によって，もしこの光量子 情報の研究にご関心を持って頂ければ，幸いである。

ここで紹介した研究は, 岡本亮助教, 藤原正澄助教を 初めとする, 量子情報フォトニクス研究分野のスタッ フ, 学生各位, ならびに, ブリストル大学の O’Brien 教 授, 広島大学の Hofmann 准教授, ならびに北海道大学 笹木敬司教授との共同研究である。またこれらの研究に 対する, JST-CREST, 総務省 SCOPE, 文部科学省科学 研究費, 科学技術振興調整費, 大和日英基金, 光科学技 術研究振興財団のご支援に,この場を㧍借りして感謝する。

\section{文献}

1) C.H. Bennett and G. Brassard : Proceedings of the IEEE International Conference on Computer, Systems, and Signal Processing, Bangalore, India (IEEE, New York), 175 (1984).
2) D. Deutsch : Proc. R. Soc. London Ser. A 400, 97 (1985).

3) 富田章久: 電子情報通信学会和文論文誌 A, Vol. J90A, 358 (2007).

4) 竹内繁樹: “量子コンピュータ”(講談社ブルーバッ クス, 2005).

5) http://www.uqcc2010.org/jp/index.html

6) M. Fujiwara, K. Toubaru and S. Takeuchi : Opt. Exp. 19, 8596 (2011).

7) M. Fujiwara, K. Toubaru, T. Noda, H.Q. Zhao and S. Takeuchi : Nano Lett. 11, 4362 (2011).

8) H.Q. Zhao, M. Fujiwara and S. Takeuchi : 日本物理学会 2011 年秋季大会, 21pPSB-50 (2011).

9) K.M.C. Fu, C. Santori, P.E. Barclay, L.J. Rogers, N.B. Manson and R.G. Beausoleil : Phys. Rev. Lett. 103, 256404 (2009).

10) C.K. Hong, Z.Y. Ou and L. Mandel : Phys. Rev. Lett. 59, 2044 (1987).

11) R. Okamoto, J.L. O’Brien, H.F. Hofmann, T. Nagata, K. Sasaki and S. Takeuchi : Science 323, 483 (2009).

12) H.F. Hofmann and S. Takeuchi : Phys. Rev. Lett. 88, 147902 (2002).

13) E. Knill, R. Laflamme and G. Milburn : Nature 409, 46 (2001)

14) R. Okamoto, J. O’Brien, H.F. Hofmann and S. Takeuchi : PNAS 108, 10067 (2011).

15) T. Nagata, R. Okamoto, J. O’Brien, K. Sasaki and S. Takeuchi : Science 316, 726 (2007).

16) K. Tsujino, H.F. Hofmann, S. Takeuchi and K. Sasaki : Phys. Rev. Lett. 92, 153602 (2004). 